\title{
MicroRNA regulation of tumorigenesis, cancer progression and interpatient heterogeneity: towards clinical use
}

\author{
S Patrick Nana-Sinkam ${ }^{1,2^{*}}$ and Carlo M Croce ${ }^{2,3^{*}}$
}

\begin{abstract}
In the past two decades, microRNAs have emerged as crucial mediators of organ development and human

disease. Here, we discuss their role as drivers or

suppressors of the hallmarks of cancer during

tumorigenesis and progression, in defining

interpatient heterogeneity and the promise of

therapeutic application.
\end{abstract}

\section{Introduction}

Cancer continues to generate a significant global medical and socioeconomic burden, despite molecular-based screening, targeted therapeutics, and our increased understanding of the molecular pathogenesis of tumor initiation and progression. As we move into an era of personalized cancer management, an increased understanding of cancer risk and tumor heterogeneity will be essential to the success of early detection and new targeted therapies. High-throughput platforms designed to interrogate the human genome and proteome are successfully being used to improve our understanding of the heterogeneity that exists within both solid and hematological malignancies, and to develop clinical biomarkers and discover new therapeutic targets.

In the past two decades, investigators have identified non-coding components of the human genome, such as microRNAs (miRNAs), as critical mediators of organ development and human disease [1]. miRNAs are non-coding RNAs 18-25 nucleotides in length that are endogenously processed in the cell and then target RNA for silencing either by RNA degradation or inhibition of transcription

\footnotetext{
* Correspondence: Patrick.Nana-Sinkam@osumc.edu; Carlo.Croce@osumc.edu 'Division of Pulmonary, Allergy, Critical Care and Sleep Medicine, The Ohio State University, 473 West 12th Avenue, Columbus, Ohio 43210, USA

${ }^{2}$ James Comprehensive Cancer Center, The Ohio State University, 300 West 10th Avenue, Columbus, Ohio 43210, USA

Full list of author information is available at the end of the article
}

(Figure 1) [2]. Given the fact that miRNAs have the capacity to regulate tens to hundreds of mRNAs, this can result in the simultaneous regulation of multiple biological pathways [3,4]. miRNAs tend to be localized to fragile chromosomal regions that are susceptible to deletions, translocations and amplifications [5]. These same chromosomal regions are often altered in cancers. Additionally, miRNAs may exist within introns or exons (harboring an independent promoter) or within a host gene [6]. Furthermore, the mechanisms by which epigenetic, genetic and environmental factors converge to regulate miRNAs in cancer are also complex and continue to be uncovered.

The applications of miRNAs in the clinical management of cancers are starting to be realized, as evidenced by an increasing number of miRNA-based clinical trials. Specifically, miRNAs are being applied as both prognostic and therapeutic biomarkers in the setting of clinical trials. The goal is to use miRNAs as another means for delineating the molecular and clinical heterogeneity that exist within cancers (Table 1). As we increasingly apply high-throughput strategies, such as genome sequencing, and identify additional oncogenic mutations that drive tumorigenesis and define heterogeneity, it is likely that a larger role for miRNAs in cancer biology will be uncovered.

The early observations that miRNAs are globally dysregulated in cancer suggested that miRNAs may contribute to both the initiation and progression of cancers [16-18]. Since these initial observations, miRNAs have been implicated as either effectors or targets of almost all of the hallmarks of cancer, including proliferation, resisting cell death, avoiding growth suppression, angiogenesis, replicative immortality and invasion/metastasis [19-23]. The roles of miRNAs as key regulators of each of these hallmarks of cancer continue to be extensively investigated and have been previously reviewed [24]. As investigators continue to identify new mechanisms for cancer initiation and progression, and to elucidate the relative contributions of the primary tumor and components of 


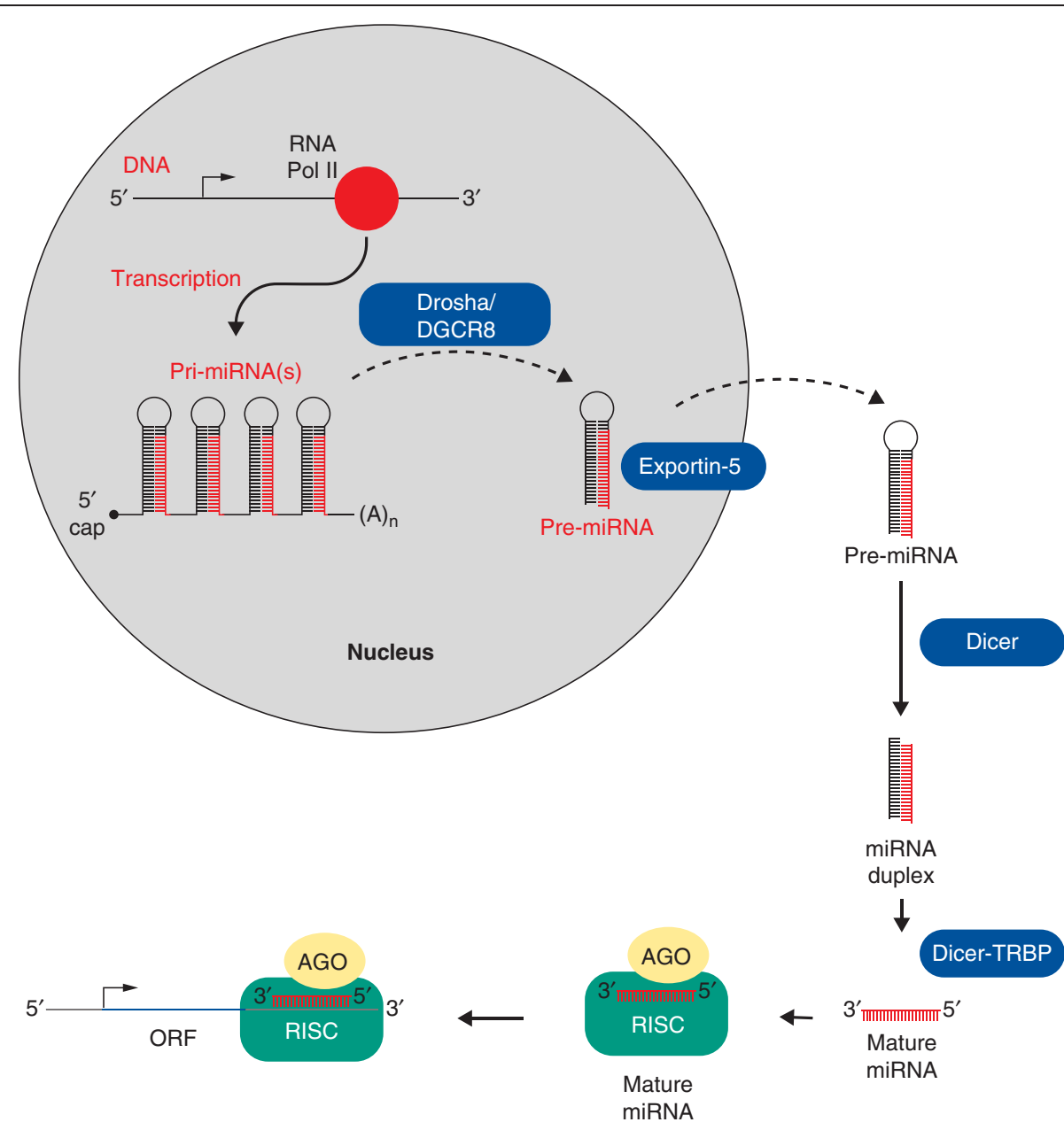

Figure 1 MicroRNA processing. During microRNA (miRNA) biogenesis, a primary miRNA transcript (pri-miRNA) is generated by an RNA polymerase (Pol) II (or III, not shown). This is followed by cleavage of the pri-miRNA by the microprocessor complex Drosha-DGCR8 (Pasha). This results in generation of the pre-miRNA, which is then exported from the nucleus by Exportin-5-Ran-GTP. Once in the cytoplasm, the RNase Dicer induces cleavage of the pre-miRNA hairpin to a double stranded mature length. The functional strand of the mature miRNA is loaded together with Argonaute (Ago2) proteins into the RNA-induced silencing complex (RISC). This complex then guides the miRNA to target mRNAs for mRNA cleavage, translational repression or deadenylation. ORF, open reading frame; TRBP, trans-activation response RNA-binding protein.

its environment to carcinogenesis, the eventual application of miRNAs in human cancer will come to fruition. For example, the recent observation that miRNAs may be integral to reprogramming of energy metabolism in cancer has provided an additional layer of complexity to miRNAs in cancer and led to the identification of new targets.

Here, rather than attempt to review the broad field of miRNAs in cancer biology, we provide an overview of some of the most promising and emerging areas in miRNA investigation. In particular, we focus on miRNAs as regulators of metabolic programming, their role in metastasis, the new concept of extracellular vesicular miRNAs as drivers of tumorigenesis and, lastly, the biological links between miRNAs and established oncogenic mutations. Each of these new and exciting areas has the potential for translating to clinical application.

\section{MicroRNAs and metabolic reprogramming in cancer}

The contribution of metabolic reprogramming of cancer cells to a largely glycolytic pathway to tumor initiation and progression remains poorly understood. However, there is increasing evidence that tumor dependence on anaerobic glycolysis regardless of oxygen stores (known as the Warburg effect) is driven by both tumor suppressors and oncogenes [25,26]. This metabolic shift confers a biological advantage to cancer cells, thus supporting both initiation and progression of tumors. Several miRNAs have been shown to regulate cancer cell metabolism, either through direct regulation of components of glycolysis or by targeting key oncogenic pathways.

The discovery that the miR-15a/16/1 cluster is downregulated or deleted in chronic lymphocytic leukemia was one of the first observations of miRNA deregulation 
Table 1 Selected microRNA-based clinical trials

\begin{tabular}{|c|c|c|c|c|}
\hline Cancer type & Type of trial & Intervention or tissue type & Clinical application & Reference \\
\hline Hepatocellular or liver metastasis & Therapeutic & miR-34 delivery (MRK-34) & Phase 1 toxicity trial & [7] \\
\hline Thyroid & Biomarker & Tissue (fine needle aspiration) & Diagnosis, chemoresponse & [8] \\
\hline Breast & Biomarker & Blood & Prognosis, surveillance, cardiotoxicity & [9] \\
\hline Breast & Biomarker & Tissue & Chemoresponse, diagnosis & [9] \\
\hline Glioma & Biomarker & Tissue & miR-10b levels in diagnosis and prognosis & {$[10]$} \\
\hline Leukemia & Biomarker & Blood & miR-155 as predictor of graft versus host disease & [11] \\
\hline Lung & Biomarker & Tissue & Chemoresponse & \\
\hline Neuroblastoma & Biomarker & Tissue & Prognosis, tumor classification & [12] \\
\hline Colon & Biomarker & Tissue & Disease stratification, chemoresponse & [13] \\
\hline Renal & Biomarker & Cell & Tissue chemoresponse & [14] \\
\hline Esophageal & Biomarker & Tissue & Predictor of response to zinc & \\
\hline Melanoma & Biomarker & Blood & Predictor of response to propranolol & [15] \\
\hline
\end{tabular}

miR, microRNA.

in cancer [22]. This initial observation further supported the concept of miRNAs being localized to fragile chromosomal regions. We identified both aldolase A (ALDOA) and triosephosphate isomerase 1 (TPI1), which have been both implicated in glycolysis, as potential targets for miR$15 \mathrm{a} / 16-1$. ALDOA is central to the glycolytic process and its overexpression in lung cancer has been associated with poor survival [27]. Since these initial observations, several other miRNAs have been identified as regulators of components of metabolic pathways in cancer. For example, monocarboxylate transporters (MCTs) contribute to lactate homeostasis through both influx and efflux across cell membranes. As a result, targeting MCTs is a viable therapeutic approach in cancer. Several tumor suppressor miRNAs, including miR-29b, have been shown to target components of lactate generation, including MCTs [28]. A third example of miRNA-mediated regulation of cellular metabolism involves one of the earliest described miRNAs. First described in Caenorhabditis elegans as crucial to larval development [29], Lin-28 is a highly conserved RNA-binding protein that has been shown to regulate glycolytic enzymes, components of mitochondrial oxidative phosphorylation and the miRNA Let-7 [29]. In addition, Lin-28 has emerged as an oncogene [30]. A recent study showed that Lin-28a is essential to programming bioenergetics during embryonal development and that Lin-28a-driven reprogramming of metabolism contributes to tissue repair [31]. The potential links between Lin-28 and cancer metabolism are still being investigated. Lastly, Singh and colleagues [32] recently identified a new link between miRNA deregulation, cancer metabolism and tumor progression. The authors [32] observed that the redox-sensitive basic leucine zipper family transcription factor nuclear factor erythroid-2-related factor 2 promotes tumorigenesis both in vitro and in a murine model through epigenetic regulation of miR-1 and miR-206. This leads to reprogramming of glucose metabolism through activation of components of the pentose phosphate pathway. The relationships between miR-1, miR-206 and components of the pentose phosphate pathway were also observed in human tissues [32].

The biological relationships between miRNAs and components of cellular metabolism continue to be established particularly in the setting of tumorigenesis. These findings will further serve to drive our understanding of the biology of cancer metabolism in tumor progression miRNAs as potential therapeutic targets in altering these important pathways.

\section{MicroRNAs and metastasis}

Metastatic disease is a major cause of mortality in solid malignancies. For instance, in lung cancer, less than $20 \%$ of patients present with localized disease. Thus, the identification of actionable targets that can be used clinically both as biomarkers and as potential therapeutic targets in the metastatic setting is essential. The process by which tumors progress to metastatic disease is a complex one. This process relies on a sequence of events that integrate both cues from the primary tumor and the surrounding microenvironment. Epithelial-mesenchymal transition (EMT) is a central mechanism that drives the eventual detachment, invasion, circulation and extravasation of cancer cells that define the metastatic process [33]. miRNAs have been shown to regulate the metastatic process by either targeting components of EMT, targeting signaling pathways that drive EMT or by selective targeting of other miRNAs. Given that miRNAs are increasingly being used as both directed therapies and as diagnostic/prognostic biomarkers, one could envision select miRNAs being targeted in cases of metastatic disease or being used as biomarkers to monitor tumor response or recurrence. 
The miR-200 family is perhaps the best-studied group of miRNAs that are known to target key transcriptional drivers of EMT, such as ZEB-1 and ZEB-2 [34-37]. For example, Davalos et al. [38] showed that miR-200 is susceptible to dynamic methylation silencing in cancer cells with mesenchymal properties but is unmethylated in tumors maintaining epithelial characteristics. In addition, tumor-suppressive miRNAs are also susceptible to regulation by mediators of EMT during metastasis. For example, Yang and colleagues [39] determined in a murine model of Kras-induced lung adenocarcinoma that a subpopulation of metastasis-prone cancer cells were dependent on Jagged2 for their metastatic potential both in vitro and in vivo. Furthermore, they determined that Jagged 2 drives metastasis through the downregulation of miR-200 [39]. A separate study [40] showed that members of the miR-200 family are not the only miRNAs implicated in the metastatic process. ZEB1 promotes metastasis through the downregulation of the tumor suppressor miR-34a [40]. The observation that miRNAs may either drive or suppress hallmarks of cancer through direct or indirect regulation of other miRNAs is a relatively new one that has emerged in the past few years. For example, this concept has been observed in promoting the metastatic process. A recent study by Song et al. [41] demonstrated that miR-22 could contribute to and promote metastases in breast cancer through miRNA regulation. The investigators showed both in vitro and in vivo that miR-22 can suppress miR-200 through direct targeting of members of the Ten eleven translocation family, thus leading to hypermethylation of members of the miR-200 family [38].

The process of metastasis is a complex one that currently lacks any therapeutic target. As a result, metastatic cancers can be extremely challenging to treat. The increasing number of studies linking miRNAs, particularly members of the miR-200 family, to components of EMT has increased our understanding of the biology of EMT and the potential for miRNAs as regulators of EMT. Although these studies have yet to translate to clinical application, they do provide the opportunity for using miRNAs as biomarkers of therapeutic response in cases of advanced disease or in the setting of surveillance.

\section{Extracellular microRNAs as drivers of tumorigenesis}

One particular area that has evaded investigators has been the process by which miRNAs may drive local and distant tumor-environment interactions. Recently, studies have shown that miRNAs may circulate either freely packaged within extracellular vesicles (EVs) or bound to specific proteins (such as the miRNA processing molecule Ago2) [42-44]. EVs are a family of small membrane-encapsulated fluid particles, comprising shedding microvesicles and exosomes, that are released from either multivesicular bodies or directly from plasma membranes [45]. EVs are released from a wide variety of cell types by independent cellular mechanisms and have become the focus of intense investigation $[45,46]$. Studies have shown that, in cancers, both tumor- and stromal-derived EVs (and their contents, including miRNAs) may function as conduits for the transport and release of mediators that drive or suppress the immune response, angiogenesis, inflammation, extracellular matrix remodeling and invasion/metastasis [47-50]. EVs 'communicate' with cells by fusing to the plasma membrane and delivering their functional cargo of proteins, lipids, mRNAs or miRNAs.

We recently identified an additional biological function for exosomal miRNAs [51]. We demonstrated [51] that exosomes may serve as ligands for Toll-like receptor- 8 (TLR-8) in humans and its homolog Tlr7 in mice. We determined that certain miRNAs, including miR-21 and miR-29, compartmentalized within exosomes could activate the TLR-8 in a recipient cell to activate an inflammatory pro-metastatic response involving nuclear factor $\mathrm{kB}$ and the secretion of tumor necrosis factor alpha and interleukin-6 [51]. These observations suggested an additional paracrine function for miRNA in driving the metastatic process that could be targeted.

Exosomes and microvesicles, which range in size from 30 to $1,000 \mathrm{~nm}$, are detectable in several body fluids ranging from plasma to urine to sputum and are the likely explanation for the observed stability of miRNAs in body fluids [52]. As a result, they are being investigated as potential non-invasive biomarkers in several cancers. Early studies [53-56] demonstrated that circulating exosomes could be used as potential diagnostic tools in ovarian, lung and prostate cancers.

Our understanding of EVs in tumorigenesis remains in its infancy; however, several studies now suggest that they may be central to intercellular communication in cancer. Additionally, their discovery supports a new area of investigation of EVs as non-invasive biomarkers of disease. Lastly, an interesting but relatively unexplored therapeutic strategy for cancer involves the directed targeting of EVs.

\section{MicroRNAs in cancer heterogeneity}

High-throughput analyses of the human genome have led to the discovery of several previously unrecognized somatic mutations that contribute to the development of both solid and hematological malignancies. In several cancers, including lung cancer, assessment of patients for specific, more common mutations has become standard of care to guide the use of therapies that target those mutations; however, several relatively common mutations in cancer remain without effective therapies. For patients with these mutations in particular, miRNAs that function as effectors, targets and predictive biomarkers in mutationdriven cancers can provide us with additional insight into 
the underlying mechanisms involved and help guide drug development and therapeutic decisions. Below, we provide some examples of more common mutations that are being applied in the clinical setting.

\section{Kras}

Approximately 20-25\% of tumors harbor mutations in genes encoding Ras family proteins, with Kras being the most common. Through activation of downstream molecules, including the Raf-MEK-ERK and PI3K-Akt pathways, Kras signaling confers both a growth and survival advantage to tumors. Although many Kras-targeted therapeutics are in clinical trials, none have yet been approved for use in the clinic. The primary reason for the lack of therapeutic targets in Kras-driven cancers is the recognized complexity of Kras signaling. Thus, it is imperative that investigators continue to identify new actionable pathways that may be eventually applied in the large percentage of cancers that harbor these mutations.

Several miRNAs have been found to regulate Kras, including Let-7, one of the earliest described tumor suppressor miRNAs that has been shown to be downregulated in cancers [57]. This initial observation has led several researchers to identify polymorphisms within the Let7-complementary Kras 3' untranslated regions [58-61] and Let-7 expression as prognostic biomarkers in cancer. Furthermore, given the establishment of Let-7 as a tumor suppressor, Let-7 has been systemically delivered in vivo as a directed therapeutic in lung cancer $[62,63]$. Two additional miRNAs, miR-30b and miR-27, have been also validated as direct regulators of Kras and function as tumor suppressors in solid cancers [64,65]. A separate study demonstrated that use of a miR-34 mimic could function as a tumor suppressor and be applied as a directed therapeutic in a murine model of Kras-induced lung tumorigenesis [66]. Conversely, the inhibition of miRNAs such as miR-143 and miR-145 by oncogenic Ras signaling has been identified as a mechanism for driving tumor progression [67]. The miRNA miR-21 is consistently deregulated in cancers, including lung, glioblastoma and B-cell lymphoma [68-70], and Hatley et al. [71] demonstrated that miR-21 is a potent driver of lung tumorigenesis in a murine model of Kras-induced lung adenocarcinoma. They showed that miR-21 directly antagonizes inhibitors of Ras, including sprouty1, sprouty2, B-cell translocation gene 2 and programmed cell death 4 [71].

\section{Epidermal growth factor receptor}

The discovery of epidermal growth factor receptor (EGFR) mutations in lung cancer was a major step forward, as was the successful targeting of EGFR-mutated tumors using EGFR tyrosine kinase inhibitors (TKIs such as gefitinib or erlotinib), which enables individualized therapy in approximately $10 \%$ of patients with lung cancer [72].
Interestingly, miRNAs may both drive EGFR signaling and serve as targets for EGFR signaling.

A recent elegant study by Shen and colleagues [73] determined that Ago2 could function as a binding partner for EGFR. In particular, in response to hypoxia, EGFR directly phosphorylates Ago2 at Tyr393, thus interfering with precursor miRNA loading and processing. Other studies have attempted to correlate EGFR mutational status with patterns of miRNA expression. Investigators have also attempted to use miRNAs as EGFR-specific diagnostic biomarkers. For example, Bjaanaes et al. [74] identified 17 miRNAs, including miR-184 and miR-30d, that distinguished EGFR-mutated lung adenocarcinomas from wildtype tumors. Additionally, they identified three miRNAs that distinguished Kras-mutated lung cancers from wildtype tumors; however, the biological significance of most of these miRNAs and their validation as Kras-specific biomarkers remains relatively unexplored [74]. In an independent investigation, miR-21 levels were identified as a predictor of response to EGFR TKI therapy [75].

For clinicians, managing the development of EGFR inhibitor resistance in patients continues to be a major obstacle. Although several mechanisms for intrinsic resistance to EGFR inhibitors have been identified, a substantial percentage of resistance develops with no known mechanism. Investigators have demonstrated that particular miRNAs may function as actionable targets in managing resistance. Park et al. [76] discovered that CRIPTO-mediated (an EGF-CFC protein family member involved in transforming growth factor $\beta$ signaling) downregulation of miR-205, which leads to EMT and activation of the Src oncogene pathway, is a mechanism for EGFR inhibitor resistance in non-small-cell lung cancer. Re-expression of miR-205 led to downregulation of EMT and Src activation, and restored EGFR-inhibitor sensitivity, suggesting that miR-205 may serve as a predictive biomarker of response to EGFR inhibition [76]. Another example in which it would be useful to predict which patients would benefit from EGFR antibody therapy is metastatic colorectal cancer. Although targeting EGFR using monoclonal antibodies, such as cetuximab and panitumumab, has proven successful in metastatic colorectal carcinoma, less than half of patients with Kras wild-type tumors are responsive to EGFR targeting. miR-31-3p expression was identified as a predictive biomarker in colorectal cancer patients receiving EGFR antibody therapy [77].

\section{Liver kinase B1}

In the late 1990s, investigators discovered that a germline inactivating mutation in the serine threonine kinase liver kinase B1 ( $L K B 1)$ gene increased susceptibility to Peutz-Jeghers syndrome, which manifests as sporadic benign and malignant tumors in several organs [78]. LKB1 activates several downstream kinases, including 
AMP-activated kinase, which has a role in cellular energy homeostasis. In energy-deficient states in particular, LKB1 functions as a tumor suppressor [79]. Several studies have since shown that somatic mutations leading to LKB1 inactivation may contribute to the pathogenesis of malignancies, including breast, liver, colorectal and lung, by metabolic reprogramming of the cancer cell and conferring a growth and metastatic advantage [80]. The role of miRNAs in LKB1 signaling in cancer remains poorly understood. The few studies so far have been conducted in gliomas. This gap in knowledge is of particular importance given the increasing awareness of the importance of LKB1 inactivation in solid tumors as an additional subset of cancers requiring targeted therapeutics.

In one of the earliest investigations of LKB1, Godlewski and colleagues [81] determined that miR-451 was overexpressed in gliomas and correlated with poor survival. They found that miR-451 targeted CAB39, a key component of the LKB1 complex. The investigators concluded that in normal glycemic conditions elevated miR-451 suppressed LKB1 signaling, leading to a proliferative advantage in glioma cells. Conversely, in conditions of metabolic stress, such as low glycemic states, miR-451 is decreased, and the resultant increase in LKB1 signaling promotes cell survival and motility. miRNAs may also indirectly regulate LKB1 signaling, as evidenced by the observation that miR-204 downregulation promotes migration and invasion through upregulation of Sirtuin1 (SIRT1), which leads to downregulation of LKB1 [82].

\section{Anaplastic lymphoid kinase}

Deregulation of anaplastic lymphoid kinase (ALK), a tyrosine kinase first described as part of an oncogenic fusion protein in anaplastic large-cell lymphoma (ALCL), has emerged as a biomarker that can inform therapeutic decision-making in cancer $[83,84]$. Perhaps one of the best examples is the identification and selection of sub-populations of lung cancer patients (between 2-7\%) harboring molecular rearrangements in $A L K$ who have demonstrated survival benefit with the use of ALK-targeting agents such as crizotinib [85].

Knowledge of the links between ALK biology and miRNA is growing, with several studies identifying distinct patterns of miRNA expression in $A L K^{+}$versus $A L K^{-}$malignancies, including ALCL [86]. Most of these studies have focused on ALCL. Liu et al. [87] recently identified a panel of seven miRNAs that distinguished $A L K^{+}$from $A L K^{-}$ALCLs (miR-512-3p, miR-886-5p, miR-886-3p, miR-708, miR-135b, miR-146a and miR-155), although the biological consequences of these patterns remain largely unknown. However, two recent studies in ALCL identified downregulated miR-29 as an inducer of cell survival through targeting of induced myeloid leukemia cell differentiation protein (MCL-1) [88] and downregulated
miR-16 as a driver of vascular endothelial growth factor expression in $A L K^{+}$disease [89]. Additionally, the c-Mycdriven cluster miR-17-92 has been shown to serve as a mediator of signal transducer and activator of transcription signaling in $A L K^{+}$ALCL [90], thus supporting a role for miRNAs in the biology of ALK signaling.

\section{Conclusions}

In the past two decades, miRNAs have emerged as molecules central to cancer biology. miRNAs represent an additional layer of complexity to cancer biology and have been further validated as regulators of processes fundamental to cancer. The rapid expansion in knowledge regarding the molecular underpinnings of cancer initiation and progression and identification of new somatic mutations has only served to expand the landscape of cancer biology. miRNAs clearly have an integral role in driving cancer. This is a field that is rapidly changing, with metabolic reprogramming and extracellular vesicular biology representing two of the most recent potential actionable targets.

Here, we have reviewed emerging concepts in miRNAs as drivers of cancer heterogeneity and progression with a focus on metabolic reprogramming, metastasis and extracellular vesicular biology. Over the past 10 years, we have moved from a phase of recognition of the global deregulation of miRNAs in cancer to one of validation of miRNAs as tumor suppressors or oncogenes, and we are moving to a future that includes clinical trials with miRNAs as therapeutic biomarkers and as directed therapies. For example, miRNAs including miR-122 and miR34 are currently in clinical trials as directed therapies in hepatitis $\mathrm{C}$ and hepatocellular carcinoma, respectively. There remain several obstacles to miRNAs reaching their full clinical application. These include improving our understanding of their fundamental biology in regulating biological pathways, developing improved methods for their reliable detection and the development of new and safe methods for in vivo delivery. Although miRNAs have yet to reach clinical practice, they are poised to do so in the near future.

\section{Abbreviations}

ALCL: anaplastic large-cell lymphoma; ALK: anaplastic lymphoid kinase; EGFR: epidermal growth factor receptor; EMT: epithelial-mesenchymal transition; EV: extracellular vesicle; LKB1: liver kinase B1;

MCT: monocarboxylate transporter; miRNA: microRNA; TKI: tyrosine kinase inhibitor; TLR: Toll-like receptor.

\section{Competing interests}

The authors declare that they have no competing interests.

\section{Author details}

'Division of Pulmonary, Allergy, Critical Care and Sleep Medicine, The Ohio State University, 473 West 12th Avenue, Columbus, Ohio 43210, USA. ${ }^{2}$ James Comprehensive Cancer Center, The Ohio State University, 300 West 10th Avenue, Columbus, Ohio 43210, USA. ${ }^{3}$ Department of Molecular Virology, Immunology \& Medical Genetics, The Ohio State University, 410 West 10th Avenue, Columbus, Ohio 43210, USA. 


\section{Published online: 31 August 2014}

\section{References}

1. Olsen PH, Ambros V: The lin-4 regulatory RNA controls developmental timing in Caenorhabditis elegans by blocking LIN-14 protein synthesis after the initiation of translation. Dev Biol 1999, 216:671-680.

2. Robins H, Li Y, Padgett RW: Incorporating structure to predict microRNA targets. Proc Natl Acad Sci USA 2005, 102:4006-4009.

3. Volinia S, Galasso M, Costinean S, Tagliavini L, Gamberoni G, Drusco A, Marchesini J, Mascellani N, Sana ME, Abu Jarour R, Desponts C, Teitell M, Baffa R, Aqeilan R, lorio MV, Taccioli C, Garzon R, Di Leva G, Fabbri M, Catozzi M, Previati M, Ambs S, Palumbo T, Garofalo M, Veronese A, Bottoni A, Gasparini P, Harris CC, Visone R, Pekarsky Y, et al: Reprogramming of miRNA networks in cancer and leukemia. Genome Res 2010, 20:589-599.

4. Esteller M: Non-coding RNAs in human disease. Nat Rev Genet 2011, 12:861-874.

5. Croce CM: Causes and consequences of microRNA dysregulation in cancer. Nat Rev Genet 2009, 10:704-714.

6. Calin GA, Croce CM: MicroRNA signatures in human cancers. Nat Rev Cancer 2006, 6:857-866.

7. Bader AG: miR-34 - a microRNA replacement therapy is headed to the clinic. Front Genet 2012, 3:120.

8. Dettmer MS, Perren A, Moch H, Komminoth P, Nikiforov YE, Nikiforova MN: MicroRNA profile of poorly differentiated thyroid carcinomas: new diagnostic and prognostic insights. J Mol Endocrinol 2014, 52:181-189.

9. Gasparini P, Cascione L, Fassan M, Lovat F, Guler G, Balci S, Irkkan C, Morrison C, Croce CM, Shapiro CL, Huebner K: microRNA expression profiling identifies a four microRNA signature as a novel diagnostic and prognostic biomarker in triple negative breast cancers. Oncotarget 2014, 5:1174-1184.

10. Visani M, de Biase D, Marucci G, Cerasoli S, Nigrisoli E, Bacchi Reggiani ML, Albani F, Baruzzi A, Pession A: Expression of 19 microRNAs in glioblastoma and comparison with other brain neoplasia of grades I-III. Mol Oncol 2014, 8:417-430.

11. Xiao B, Wang Y, Li W, Baker M, Guo J, Corbet K, Tsalik EL, Li QJ, Palmer SM, Woods CW, Li Z, Chao NJ, He YW: Plasma microRNA signature as a noninvasive biomarker for acute graft-versus-host disease. Blood 2013, 122:3365-3375.

12. Bienertova-Vasku J, Mazanek P, Hezova R, Curdova A, Nekvindova J, Kren L, Sterba J, Slaby O: Extension of microRNA expression pattern associated with high-risk neuroblastoma. Tumour Biol 2013, 34:2315-2319.

13. Schetter AJ, Leung SY, Sohn JJ, Zanetti KA, Bowman ED, Yanaihara N, Yuen ST, Chan TL, Kwong DL, Au GK, Liu CG, Calin GA, Croce CM, Harris CC: MicroRNA expression profiles associated with prognosis and therapeutic outcome in colon adenocarcinoma. JAMA 2008, 299:425-436.

14. Gowrishankar B, Ibragimova I, Zhou Y, Slifker MJ, Devarajan K, Al-Saleem T, Uzzo RG, Cairns P: MicroRNA expression signatures of stage, grade, and progression in clear cell RCC. Cancer Biol Ther 2014, 15:329-341.

15. Bennett $P E$, Bemis $L$, Norris DA, Shellman YG: miR in melanoma development: miRNAs and acquired hallmarks of cancer in melanoma. Physiol Genomics 2013, 45:1049-1059.

16. Volinia S, Calin GA, Liu CG, Ambs S, Cimmino A, Petrocca F, Visone R, lorio M, Roldo C, Ferracin M, Prueitt RL, Yanaihara N, Lanza G, Scarpa A, Vecchione A, Negrini M, Harris CC, Croce CM: A microRNA expression signature of human solid tumors defines cancer gene targets. Proc Natl Acad Sci USA 2006, 103:2257-2261.

17. Liu CG, Spizzo R, Calin GA, Croce CM: Expression profiling of microRNA using oligo DNA arrays. Methods 2008, 44:22-30.

18. Calin GA, Ferracin M, Cimmino A, Di Leva G, Shimizu M, Wojcik SE, lorio MV, Visone R, Sever NI, Fabbri M, Iuliano R, Palumbo T, Pichiorri F, Roldo C, Garzon R, Sevignani C, Rassenti L, Alder H, Volinia S, Liu CG, Kipps TJ, Negrini $M$, Croce CM: A microRNA signature associated with prognosis and progression in chronic lymphocytic leukemia. N Engl J Med 2005, 353:1793-1801.

19. Olson P, Lu J, Zhang H, Shai A, Chun MG, Wang Y, Libutti SK, Nakakura EK Golub TR, Hanahan D: MicroRNA dynamics in the stages of tumorigenesis correlate with hallmark capabilities of cancer. Genes Dev 2009, 23:2152-2165.

20. Valeri N, Braconi C, Gasparini P, Murgia C, Lampis A, Paulus-Hock V, Hart JR, Ueno L, Grivennikov SI, Lovat F, Paone A, Cascione L, Sumani KM, Veronese A, Fabbri M, Carasi S, Alder H, Lanza G, Gafa' R, Moyer MP, Ridgway RA,
Cordero J, Nuovo GJ, Frankel WL, Rugge M, Fassan M, Groden J, Vogt PK Karin M, Sansom OJ, et al: MicroRNA-135b promotes cancer progression by acting as a downstream effector of oncogenic pathways in colon cancer. Cancer Cell 2014, 25:469-483.

21. Chen Y, Gorski DH: Regulation of angiogenesis through a microRNA (miR-130a) that down-regulates antiangiogenic homeobox genes GAX and HOXA5. Blood 2008, 111:1217-1226.

22. Calin GA, Cimmino A, Fabbri M, Ferracin M, Wojcik SE, Shimizu M, Taccioli C, Zanesi N, Garzon R, Aqeilan Rl, Alder H, Volinia S, Rassenti L, Liu X, Liu CG, Kipps TJ, Negrini M, Croce CM: MiR-15a and miR-16-1 cluster functions in human leukemia. Proc Natl Acad Sci USA 2008, 105:5166-5171.

23. Gibbons DL, Lin W, Creighton CJ, Rizvi ZH, Gregory PA, Goodall GJ, Thilaganathan N, Du L, Zhang Y, Pertsemlidis A, Kurie JM: Contextual extracellular cues promote tumor cell EMT and metastasis by regulating miR-200 family expression. Genes Dev 2009, 23:2140-2151.

24. Dalmay T, Edwards DR: MicroRNAs and the hallmarks of cancer. Oncogene 2006, 25:6170-6175.

25. Valastyan S, Chang A, Benaich N, Reinhardt F, Weinberg RA: Activation of miR-31 function in already-established metastases elicits metastatic regression. Genes Dev 2011, 25:646-659.

26. Hanahan D, Weinberg RA: Hallmarks of cancer: the next generation. Cell 2011, 144:646-674

27. Du S, Guan Z, Hao L, Song Y, Wang L, Gong L, Liu L, Qi X, Hou Z, Shao S: Fructose-bisphosphate aldolase a is a potential metastasis-associated marker of lung squamous cell carcinoma and promotes lung cell tumorigenesis and migration. PLoS One 2014, 9:e85804.

28. Pullen TJ, da Silva XG, Kelsey G, Rutter GA: miR-29a and miR-29b contribute to pancreatic beta-cell-specific silencing of monocarboxylate transporter 1 (Mct1). Mol Cell Biol 2011, 31:3182-3194.

29. Lehrbach NJ, Armisen J, Lightfoot HL, Murfitt K, Bugaut A, Balasubramanian S, Miska EA: LIN-28 and the poly(U) polymerase PUP-2 regulate let-7 microRNA processing in Caenorhabditis elegans. Nat Struct Mol Biol 2009, 16:1016-1020.

30. Li N, Zhong X, Lin X, Guo J, Zou L, Tanyi JL, Shao Z, Liang S, Wang LP, Hwang WT, Katsaros D, Montone K, Zhao X, Zhang L: Lin-28 homologue A (LIN28A) promotes cell cycle progression via regulation of cyclin-dependent kinase 2 (CDK2), cyclin D1 (CCND1), and cell division cycle 25 homolog A (CDC25A) expression in cancer. J Biol Chem 2012, 287:17386-17397.

31. Shyh-Chang N, Zhu H, Yvanka de Soysa T, Shinoda G, Seligson MT, Tsanov KM, Nguyen L, Asara JM, Cantley LC, Daley GQ: Lin28 enhances tissue repair by reprogramming cellular metabolism. Cell 2013, 155:778-792.

32. Singh A, Happel C, Manna SK, Acquaah-Mensah G, Carrerero J, Kumar S, Nasipuri P, Krausz KW, Wakabayashi N, Dewi R, Boros LG, Gonzalez FJ, Gabrielson E, Wong KK, Girnun G, Biswal S: Transcription factor NRF2 regulates miR-1 and miR-206 to drive tumorigenesis. J Clin Invest 2013 123:2921-2934

33. Byers LA, Diao L, Wang J, Saintigny P, Girard L, Peyton M, Shen L, Fan Y, Giri U, Tumula PK, Nilsson MB, Gudikote J, Tran H, Cardnell RJ, Bearss DJ, Warner SL, Foulks JM, Kanner SB, Gandhi V, Krett N, Rosen ST, Kim ES, Herbst RS, Blumenschein GR, Lee JJ, Lippman SM, Ang KK, Mills GB, Hong WK, Weinstein JN, et al: An epithelial-mesenchymal transition gene signature predicts resistance to EGFR and PI3K inhibitors and identifies AxI as a therapeutic target for overcoming EGFR inhibitor resistance. Clin Cancer Res 2013, 19:279-290.

34. Hurteau GJ, Carlson JA, Spivack SD, Brock GJ: Overexpression of the microRNA hsa-miR-200c leads to reduced expression of transcription factor 8 and increased expression of E-cadherin. Cancer Res 2007, 67:7972-7976

35. Hurteau GJ, Carlson JA, Roos E, Brock GJ: Stable expression of miR-200c alone is sufficient to regulate TCF8 (ZEB1) and restore E-cadherin expression. Cell Cycle 2009, 8:2064-2069.

36. Gregory PA, Bert AG, Paterson EL, Barry SC, Tsykin A, Farshid G, Vadas MA, Khew-Goodall Y, Goodall GJ: The miR-200 family and miR-205 regulate epithelial to mesenchymal transition by targeting ZEB1 and SIP1. Nat Cell Biol 2008, 10:593-601.

37. Gregory PA, Bracken CP, Smith E, Bert AG, Wright JA, Roslan S, Morris M, Wyatt L, Farshid G, Lim YY, Lindeman GJ, Shannon MF, Drew PA, Khew-Goodall Y, Goodall GJ: An autocrine TGF-beta/ZEB/miR-200 signaling network regulates establishment and maintenance of epithelial-mesenchymal transition. Mol Biol Cell 2011, 22:1686-1698. 
38. Davalos V, Moutinho C, Villanueva A, Boque R, Silva P, Carneiro F, Esteller M: Dynamic epigenetic regulation of the microRNA-200 family mediates epithelial and mesenchymal transitions in human tumorigenesis. Oncogene 2012, 31:2062-2074.

39. Yang Y, Ahn YH, Gibbons DL, Zang Y, Lin W, Thilaganathan N, Alvarez CA, Moreira DC, Creighton CJ, Gregory PA, Goodall GJ, Kurie JM: The Notch ligand Jagged2 promotes lung adenocarcinoma metastasis through a miR-200-dependent pathway in mice. J Clin Invest 2011, 121:1373-1385.

40. Ahn YH, Gibbons DL, Chakravarti D, Creighton CJ, Rizvi ZH, Adams HP, Pertsemlidis A, Gregory PA, Wright JA, Goodall GJ, Flores ER, Kurie JM: ZEB1 drives prometastatic actin cytoskeletal remodeling by downregulating miR-34a expression. J Clin Invest 2012, 122:3170-3183.

41. Song SJ, Poliseno L, Song MS, Ala U, Webster K, Ng C, Beringer G, Brikbak NJ, Yuan X, Cantley LC, Richardson AL, Pandolfi PP: MicroRNA-antagonism regulates breast cancer stemness and metastasis via TET-family-dependent chromatin remodeling. Cell 2013, 154:311-324.

42. Valadi $H$, Ekstrom $K$, Bossios A, Sjostrand M, Lee JJ, Lotvall JO: Exosome-mediated transfer of mRNAs and microRNAs is a novel mechanism of genetic exchange between cells. Nat Cell Biol 2007, 9:654-659.

43. Hunter MP, Ismail N, Zhang X, Aguda BD, Lee E, Yu L, Xiao T, Schafer J, Lee ML, Schmittgen TD, Nana-Sinkam SP, Jarjoura D, Marsh CB: Detection of microRNA expression in human peripheral blood microvesicles. PLoS One 2008, 3:e3694.

44. Arroyo JD, Chevillet JR, Kroh EM, Ruf IK, Pritchard CC, Gibson DF, Mitchell PS, Bennett CF, Pogosova-Agadjanyan EL, Stirewalt DL, Tait JF, Tewari M: Argonaute2 complexes carry a population of circulating microRNAs independent of vesicles in human plasma. Proc Natl Acad Sci USA 2011, 108:5003-5008.

45. Turchinovich A, Weiz L, Langheinz A, Burwinkel B: Characterization of extracellular circulating microRNA. Nucleic Acids Res 2011, 39:7223-7233.

46. Thery C: Exosomes: secreted vesicles and intercellular communications. F1000 Biol Rep 2011, 3:15

47. Gastpar R, Gehrmann M, Bausero MA, Asea A, Gross C, Schroeder JA, Multhoff $\mathrm{G}$ : Heat shock protein 70 surface-positive tumor exosomes stimulate migratory and cytolytic activity of natural killer cells. Cancer Res 2005, 65:5238-5247.

48. Gesierich S, Berezovskiy I, Ryschich E, Zoller M: Systemic induction of the angiogenesis switch by the tetraspanin D6.1A/CO-029. Cancer Res 2006, 66:7083-7094

49. Liu C, Yu S, Zinn K, Wang J, Zhang L, Jia Y, Kappes JC, Barnes S, Kimberly RP, Grizzle WE, Zhang HG: Murine mammary carcinoma exosomes promote tumor growth by suppression of NK cell function. J Immunol 2006, 176:1375-1385.

50. Mu W, Rana S, Zoller M: Host matrix modulation by tumor exosomes promotes motility and invasiveness. Neoplasia 2013, 15:875-887.

51. Fabbri M, Paone A, Calore F, Galli R, Gaudio E, Santhanam R, Lovat F, Fadda P, Mao C, Nuovo GJ, Zanesi N, Crawford M, Ozer GH, Wernicke D, Alder H, Caligiuri MA, Nana-Sinkam P, Perrotti D, Croce CM: MicroRNAs bind to Toll-like receptors to induce prometastatic inflammatory response. Proc Natl Acad Sci USA 2012, 109:E2110-E2116.

52. Gallo A, Alevizos I: Isolation of circulating microRNA in saliva. Methods Mol Biol 2013, 1024:183-190.

53. Taylor DD, Gercel-Taylor C: MicroRNA signatures of tumor-derived exosomes as diagnostic biomarkers of ovarian cancer. Gynecol Oncol 2008, 110:13-21.

54. Rabinowits G, Gercel-Taylor C, Day JM, Taylor DD, Kloecker GH: Exosomal microRNA: a diagnostic marker for lung cancer. Clin Lung Cancer 2009, 10:42-46.

55. Cheng HH, Mitchell PS, Kroh EM, Dowell AE, Chery L, Siddiqui J, Nelson PS, Vessella RL, Knudsen BS, Chinnaiyan AM, Pienta KJ, Morrissey C, Tewari M: Circulating microRNA profiling identifies a subset of metastatic prostate cancer patients with evidence of cancer-associated hypoxia. PLoS One 2013, 8:e69239.

56. Cazzoli R, Buttitta F, Di Nicola M, Malatesta S, Marchetti A, Rom WN, Pass HI: microRNAs derived from circulating exosomes as noninvasive biomarkers for screening and diagnosing lung cancer. J Thorac Oncol 2013, 8:1156-1162.

57. Christensen BC, Moyer BJ, Avissar M, Ouellet LG, Plaza SL, McClean MD, Marsit CJ, Kelsey KT: A let-7 microRNA-binding site polymorphism in the KRAS 3' UTR is associated with reduced survival in oral cancers. Carcinogenesis 2009, 30:1003-1007.
58. Sha D, Lee AM, Shi Q, Alberts SR, Sargent DJ, Sinicrope FA, Diasio RB Association study of the let-7 miRNA-complementary site variant in the 3 ' untranslated region of the KRAS gene in stage III colon cancer (NCCTG N0147 clinical trial). Clin Cancer Res 2014, 20:3319-3327.

59. Kim M, Chen X, Chin LJ, Paranjape T, Speed WC, Kidd KK, Zhao H, Weidhaas $J B$, Slack FJ: Extensive sequence variation in the 3 ' untranslated region of the KRAS gene in lung and ovarian cancer cases. Cell Cycle 2014, 13:1030-1040

60. Kjersem JB, Ikdahl T, Guren T, Skovlund E, Sorbye H, Hamfjord J, Pfeiffer P, Glimelius B, Kersten C, Solvang H, Tveit KM, Kure EH: Let-7 miRNA-binding site polymorphism in the KRAS 3'UTR; colorectal cancer screening population prevalence and influence on clinical outcome in patients with metastatic colorectal cancer treated with 5-fluorouracil and oxaliplatin +/- cetuximab. BMC Cancer 2012, 12:534

61. Chin LJ, Ratner E, Leng S, Zhai R, Nallur S, Babar I, Muller RU, Straka E, Su L, Burki EA, Crowell RE, Patel R, Kulkarni T, Homer R, Zelterman D, Kidd KK, Zhu Y, Christiani DC, Belinsky SA, Slack FJ, Weidhaas JB: A SNP in a let-7 microRNA complementary site in the KRAS 3 ' untranslated region increases non-small cell lung cancer risk. Cancer Res 2008, 68:8535-8540.

62. Trang P, Medina PP, Wiggins JF, Ruffino L, Kelnar K, Omotola M, Homer R, Brown D, Bader AG, Weidhaas JB, Slack FJ: Regression of murine lung tumors by the let-7 microRNA. Oncogene 2010, 29:1580-1587.

63. Trang $P$, Wiggins JF, Daige $C L$, Cho C, Omotola M, Brown D, Weidhaas JB, Bader AG, Slack FJ: Systemic delivery of tumor suppressor microRNA mimics using a neutral lipid emulsion inhibits lung tumors in mice. $\mathrm{Mol}$ Ther 2011, 19:1116-1122.

64. Liao WT, Ye YP, Zhang NJ, Li TT, Wang SY, Cui YM, Qi L, Wu P, Jiao HL, Xie YJ, Zhang C, Wang JX, Ding YQ: MicroRNA-30b functions as a tumour suppressor in human colorectal cancer by targeting KRAS, PIK3CD and BCL2. J Pathol 2014, 232:415-427.

65. Zhu L, Wang Z, Fan Q, Wang R, Sun Y: microRNA-27a functions as a tumor suppressor in esophageal squamous cell carcinoma by targeting KRAS. Oncol Rep 2014, 31:280-286.

66. Kasinski AL, Slack FJ: miRNA-34 prevents cancer initiation and progression in a therapeutically resistant K-ras and p53-induced mouse model of lung adenocarcinoma. Cancer Res 2012, 72:5576-5587.

67. Kent OA, Chivukula RR, Mullendore M, Wentzel EA, Feldmann G, Lee KH, Liu S, Leach SD, Maitra A, Mendell JT: Repression of the miR-143/145 cluster by oncogenic Ras initiates a tumor-promoting feed-forward pathway. Genes Dev 2010, 24:2754-2759.

68. Yanaihara N, Caplen N, Bowman E, Seike M, Kumamoto K, Yi M, Stephens RM, Okamoto A, Yokota J, Tanaka T, Calin GA, Liu CG, Croce CM, Harris CC: Unique microRNA molecular profiles in lung cancer diagnosis and prognosis. Cancer Cell 2006, 9:189-198.

69. Chan JA, Krichevsky AM, Kosik KS: MicroRNA-21 is an antiapoptotic factor in human glioblastoma cells. Cancer Res 2005, 65:6029-6033.

70. Lawrie CH, Soneji S, Marafioti T, Cooper CD, Palazzo S, Paterson JC, Cattan H, Enver T, Mager R, Boultwood J, Wainscoat JS, Hatton CS: MicroRNA expression distinguishes between germinal center $B$ cell-like and activated $B$ cell-like subtypes of diffuse large B cell lymphoma. Int J Cancer 2007, 121:1156-1161.

71. Hatley ME, Patrick DM, Garcia MR, Richardson JA, Bassel-Duby R, van Rooij E, Olson EN: Modulation of K-Ras-dependent lung tumorigenesis by MicroRNA-21. Cancer Cell 2010, 18:282-293.

72. Sequist LV, Joshi VA, Janne PA, Muzikansky A, Fidias P, Meyerson M, Haber DA, Kucherlapati $R$, Johnson BE, Lynch TJ: Response to treatment and survival of patients with non-small cell lung cancer undergoing somatic EGFR mutation testing. Oncologist 2007, 12:90-98.

73. Shen J, Xia W, Khotskaya YB, Huo L, Nakanishi K, Lim SO, Du Y, Wang Y, Chang WC, Chen CH, Hsu JL, Wu Y, Lam YC, James BP, Liu X, Liu CG, Patel DJ, Hung MC: EGFR modulates microRNA maturation in response to hypoxia through phosphorylation of AGO2. Nature 2013, 497:383-387.

74. Bjaanaes MM, Halvorsen AR, Solberg S, Jorgensen L, Dragani TA, Galvan A, Colombo F, Anderlini M, Pastorino U, Kure E, Børresen-Dale AL, Brustugun OT, Helland A: Unique microRNA-profiles in EGFR-mutated lung adenocarcinomas. Int J Cancer 2014, 135:1812-1821.

75. Shen $Y$, Tang $D$, Yao R, Wang $M$, Wang $Y$, Yao $Y$, Li X, Zhang $H$ : microRNA expression profiles associated with survival, disease progression, and response to gefitinib in completely resected non-small-cell lung cancer with EGFR mutation. Med Oncol 2013, 30:750.

76. Park KS, Raffeld M, Moon YW, Xi L, Bianco C, Pham T, Lee LC, Mitsudomi T, Yatabe Y, Okamoto I, Subramaniam D, Mok T, Rosell R, Luo J, Salomon DS, 
Wang Y, Giaccone G: CRIPTO1 expression in EGFR-mutant NSCLC elicits intrinsic EGFR-inhibitor resistance. J Clin Invest 2014, 124:3003-3015

77. Manceau G, Imbeaud S, Thiebaut R, Liebaert F, Fontaine K, Rousseau F, Genin B, Corre DL, Didelot A, Vincent M, Bachet JB, Chibaudel B, Bouché O, Landi B, Bibeau F, Leroy K, Penault-Llorca F, Van Laethem JL, Demetter P, Tejpar S, Rossi S, Mosakhani N, Osterlund P, Ristamäki R, Sarhadi V, Knuutila $S$, Boige V, André T, Laurent-Puig P: Hsa-miR-31-3p expression is linked to progression-free survival in patients with KRAS wild-type metastatic colorectal cancer treated with anti-EGFR therapy. Clin Cancer Res 2014 20:3338-3347.

78. Hemminki A, Markie D, Tomlinson I, Avizienyte E, Roth S, Loukola A, Bignell $G$, Warren W, Aminoff $M$, Höglund $P$, Järvinen $H$, Kristo $P$, Pelin K, Ridanpää M, Salovaara R, Toro T, Bodmer W, Olschwang S, Olsen AS, Stratton MR, de la Chapelle A, Aaltonen LA: A serine/threonine kinase gene defective in Peutz-Jeghers syndrome. Nature 1998, 391:184-187.

79. Ji H, Ramsey MR, Hayes DN, Fan C, McNamara K, Kozlowski P, Torrice C, Wu MC, Shimamura T, Perera SA, Liang MC, Cai D, Naumov GN, Bao L, Contreras CM, Li D, Chen L, Krishnamurthy J, Koivunen J, Chirieac LR, Padera RF, Bronson RT, Lindeman NI, Christiani DC, Lin X, Shapiro Gl, Jänne PA, Johnson BE, Meyerson M, et al: LKB1 modulates lung cancer differentiation and metastasis. Nature 2007, 448:807-810.

80. Roy BC, Kohno T, Iwakawa R, Moriguchi T, Kiyono T, Morishita K, Sanchez-Cespedes M, Akiyama T, Yokota J: Involvement of LKB1 in epithelial-mesenchymal transition (EMT) of human lung cancer cells. Lung Cancer 2010, 70:136-145.

81. Godlewski J, Nowicki MO, Bronisz A, Nuovo G, Palatini J, De Lay M, Van Brocklyn J, Ostrowski MC, Chiocca EA, Lawler SE: MicroRNA-451 regulates LKB1/AMPK signaling and allows adaptation to metabolic stress in glioma cells. Mol Cell 2010, 37:620-632.

82. Zhang L, Wang $X$, Chen P: MiR-204 down regulates SIRT1 and reverts SIRT1-induced epithelial-mesenchymal transition, anoikis resistance and invasion in gastric cancer cells. BMC Cancer 2013, 13:290.

83. Horn L, Pao W: EML4-ALK: honing in on a new target in non-small-cell lung cancer. J Clin Oncol 2009, 27:4232-4235.

84. Lin E, Li L, Guan Y, Soriano R, Rivers CS, Mohan S, Pandita A, Tang J, Modrusan Z: Exon array profiling detects EML4-ALK fusion in breast, colorectal, and non-small cell lung cancers. Mol Cancer Res 2009, 7:1466-1476.

85. Shaw AT, Kim DW, Nakagawa K, Seto T, Crino L, Ahn MJ, De Pas T, Besse B, Solomon BJ, Blackhall F, Wu YL, Thomas M, O'Byrne K, Moro-Sibilot D, Camidge DR, Mok T, Hirsh V, Riely GJ, lyer S, Tassell V, Polli A, Wilner KD, Jänne PA: Crizotinib versus chemotherapy in advanced ALK-positive lung cancer. N Engl J Med 2013, 368:2385-2394.

86. Merkel O, Hamacher F, Laimer D, Sifft E, Trajanoski Z, Scheideler M, Egger G, Hassler MR, Thallinger C, Schmatz A, Turner SD, Greil R, Kenner $L$ : Identification of differential and functionally active miRNAs in both anaplastic lymphoma kinase (ALK) + and ALK- anaplastic large-cell lymphoma. Proc Natl Acad Sci USA 2010 107:16228-16233.

87. Liu C, Iqbal J, Teruya-Feldstein J, Shen Y, Dabrowska MJ, Dybkaer K, Lim MS, Piva R, Barreca A, Pellegrino E, Spaccarotella E, Lachel CM, Kucuk C, Jiang CS, Hu X, Bhagavathi S, Greiner TC, Weisenburger DD, Aoun P, Perkins SL, McKeithan TW, Inghirami G, Chan WC: MicroRNA expression profiling identifies molecular signatures associated with anaplastic large cell lymphoma. Blood 2013, 122:2083-2092.

88. Desjobert C, Renalier MH, Bergalet J, Dejean E, Joseph N, Kruczynski A, Soulier J, Espinos E, Meggetto F, Cavaillé J, Delsol G, Lamant L: MiR-29a down-regulation in ALK-positive anaplastic large cell lymphomas contributes to apoptosis blockade through MCL-1 overexpression. Blood 2011, 117:6627-6637.
89. Dejean E, Renalier MH, Foisseau M, Agirre X, Joseph N, de Paiva GR, Al Saati T, Soulier J, Desjobert C, Lamant L, Prósper F, Felsher DW, Cavaillé J, Prats H, Delsol G, Giuriato S, Meggetto F: Hypoxia-microRNA-16 downregulation induces VEGF expression in anaplastic lymphoma kinase (ALK)-positive anaplastic large-cell lymphomas. Leukemia 2011, 25:1882-1890.

90. Spaccarotella E, Pellegrino E, Ferracin M, Ferreri C, Cuccuru G, Liu C, labal J, Cantarella D, Taulli R, Provero P, Di Cunto F, Medico E, Negrini M, Chan WC, Inghirami G, Piva R: STAT3-mediated activation of microRNA cluster $17 \sim 92$ promotes proliferation and survival of ALK-positive anaplastic large cell lymphoma. Haematologica 2014, 99:116-124.

doi:10.1186/s13059-014-0445-8

Cite this article as: Nana-Sinkam and Croce: MicroRNA regulation of tumorigenesis, cancer progression and interpatient heterogeneity: towards clinical use. Genome Biology 2014 15:445. 